\title{
Review \\ The Role of Glycoside Hydrolases in Phytopathogenic Fungi and Oomycetes Virulence
}

\author{
Vahideh Rafiei, Heriberto Vélëz and Georgios Tzelepis *
}

check for updates

Citation: Rafiei, V.; Vélëz, H.;

Tzelepis, G. The Role of Glycoside

Hydrolases in Phytopathogenic Fungi and Oomycetes Virulence. Int. J. Mol. Sci. 2021, 22, 9359. https://doi.org/ $10.3390 /$ ijms22179359

Academic Editor: Christophe Morisseau

Received: 28 July 2021

Accepted: 25 August 2021

Published: 28 August 2021

Publisher's Note: MDPI stays neutral with regard to jurisdictional claims in published maps and institutional affiliations.

Copyright: (c) 2021 by the authors. Licensee MDPI, Basel, Switzerland. This article is an open access article distributed under the terms and conditions of the Creative Commons Attribution (CC BY) license (https:/ / creativecommons.org/licenses/by/ $4.0 /)$.
Department of Forest Mycology and Plant Pathology, Swedish University of Agricultural Sciences, Uppsala Biocenter, Box 7026, SE-750 07 Uppsala, Sweden; vahideh.rafiei@slu.se (V.R.); heriberto.velez@slu.se (H.V.)

* Correspondence: Georgios.tzelepis@slu.se; Tel.: +46-18-67181503

Abstract: Phytopathogenic fungi need to secrete different hydrolytic enzymes to break down complex polysaccharides in the plant cell wall in order to enter the host and develop the disease. Fungi produce various types of cell wall degrading enzymes (CWDEs) during infection. Most of the characterized CWDEs belong to glycoside hydrolases (GHs). These enzymes hydrolyze glycosidic bonds and have been identified in many fungal species sequenced to date. Many studies have shown that CWDEs belong to several GH families and play significant roles in the invasion and pathogenicity of fungi and oomycetes during infection on the plant host, but their mode of function in virulence is not yet fully understood. Moreover, some of the CWDEs that belong to different GH families act as pathogenassociated molecular patterns (PAMPs), which trigger plant immune responses. In this review, we summarize the most important GHs that have been described in eukaryotic phytopathogens and are involved in the establishment of a successful infection.

Keywords: carbohydrate-active enzymes; cell wall degrading enzymes; pathogenicity; phytopathogens; plant-microbe interactions

\section{Introduction}

Plants have evolved effective mechanisms of resistance to cope with pathogen attack. A primary challenge for a pathogen is to breach the host cell wall, which is the fundamental physical barrier protecting plants against microbial attack [1,2]. The plant cell wall is composed of polysaccharides such as cellulose, hemicellulose, and pectin (Figure 1) [3]. To penetrate and break down this barrier, most phytopathogenic fungi and oomycetes have developed an arsenal of tools such as secreting cell wall-degrading enzymes (CWDEs) that include pectinases, polygalacturonases, glucanases, cellulases, and xyloglucanases, to degrade the components of the host cell wall [4]. Enzymes that are responsible for breaking down complex carbohydrates and polysaccharides into smaller products are called carbohydrate-active enzymes (CAZymes) [5].

Most phytopathogenic fungi and oomycetes secrete various kinds of CAZymes, and CWDEs are the most abundant and important enzymes due to their roles in penetration, invasion, and pathogenicity. Although the exact role of the majority of CWDEs have remained unknown, various studies have reported that these enzymes are important virulence factors in many plant pathogens, which can facilitate pathogen invasion and disease development, as well as providing pathogens with nutrition by carbohydrates released from the cell wall [6,7]. On the other hand, pathogen attacks can be recognized by plants through the detection of elicitor molecules, such as hydrolyzed plant cell wall components, which result in the activation of plant immune responses [8].

In general, the CAZymes have been classified into six main classes that include glycoside hydrolases, polysaccharide lyases, glycosyltransferases, carbohydrate esterases, auxiliary activity enzymes, and carbohydrate-binding modules [9]. Comparative analysis of CAZymes across all fungal species indicated that there is a great diversity in the number and types of CAZymes among fungi. For instance, phytopathogenic fungi have the greatest 
number of CAZymes, with necrotrophic and hemi-biotrophic fungal species having more CAZymes compared to biotrophic ones [10]. In this review, we have summarized the latest knowledge of CWDEs belonging to different Glycoside hydrolases families that are involved in the pathogenicity of fungi and oomycetes.

A
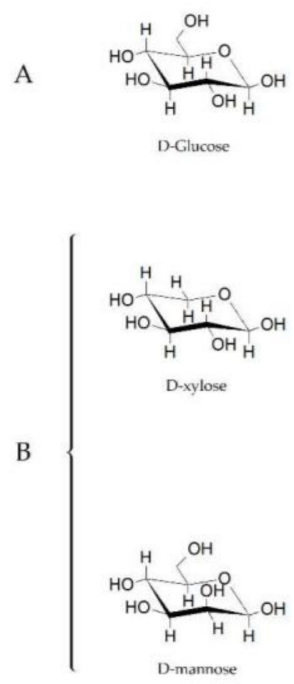

C

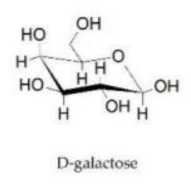

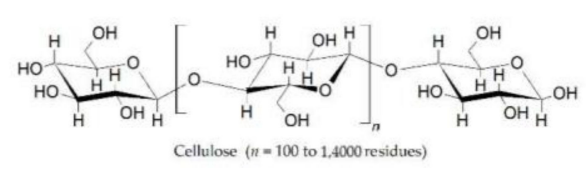
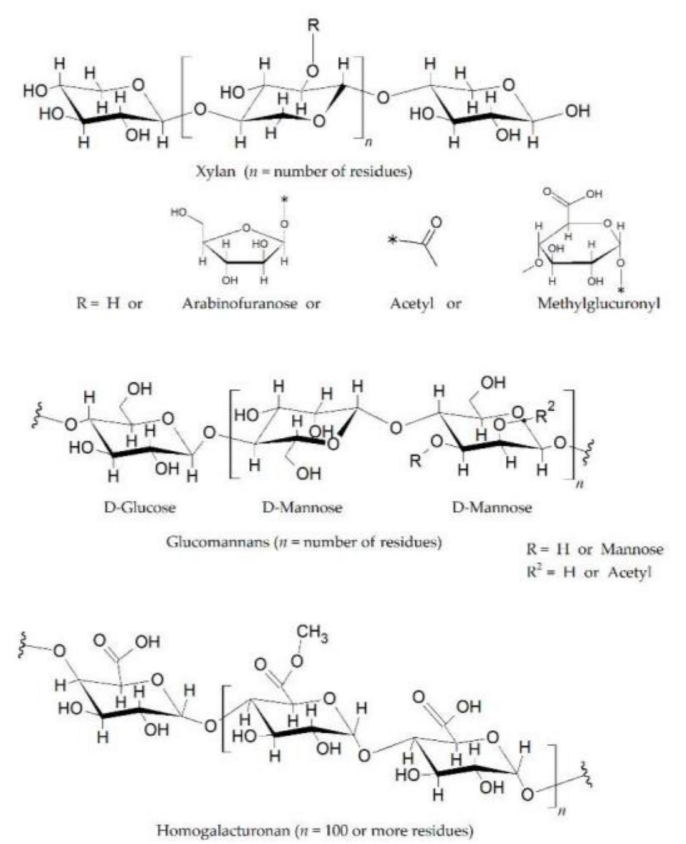

Figure 1. The plant cell wall is composed of polysaccharides such as cellulose, hemicellulose, and pectin. (A). Cellulose is a polymer of D-glucose units linked by $\beta 1-4$ bonds, also known as glucosidic bonds. (B). Xylans and glucomannans are two components of hemicellulose. The xylan backbone, which is composed of D-xylose linked together by $\beta 1-4$ bonds, also contains varying amounts of acetyl, methylglucuronyl, and arabinofuranosyl side chains. The arabinofuranosyl side chains can also be linked to aromatic acids (e.g., p-coumaric acid). Glucomannans are composed of D-glucose and D-mannose at a ratio of 1.6:1 (linked by $\beta 1-4$ bonds), and with branches of D-mannose residues at the $\mathrm{C} 3$ position ( $\beta 1-3$ bonds), on both glucose and mannose. (C). Pectin is the methylated ester of polygalacturonic acid, consisting of chains of 300 to 1000 galacturonic acid units joined with $1 \alpha \rightarrow 4$ bonds. The structure shows three methyl ester forms $(-\mathrm{COOCH} 3)$ for every two carboxyl groups $(-\mathrm{COOH})$, having a $60 \%$ degree of esterification. The substituted residues at $\mathrm{C}-4$ with neutral and acidic oligosaccharide side chain composing of arbinose, galactose, fructose, and glucuronic acid. The length of the chains and the attached residues and their placement varies among plant species [11,12]. The chemical structures have been drawn with ACD/ChemSketch (Freeware Software, version 2020.2.1, www.acdlabs.com, accessed on 20 August 2021).

\section{Glycoside Hydrolases}

Glycoside hydrolases (GHs) are the most predominant and widespread class among the fungi analyzed so far [10]. They are the largest and the most diverse characterized group of protein families in the CAZy database that are responsible for hydrolytic cleavage of the glycosidic bonds between carbohydrate molecules or between a carbohydrate and a non-carbohydrate group (e.g., lipid or sugar) [13-15]. GHs consist of 171 protein families (GH 1-171) that are classified based on amino acid sequences and structural similarities, which are all accessible in the constantly updated CAZy database at http:/ / www.cazy.org, accessed on 10 March 2021 [16]. 
GHs enzymes can break down carbohydrates and polysaccharides; however, not all pathogen genomes contain genes coding for all the GH families, and some families are present in fungi not necessarily known for their ability to degrade cellulose [10]. So far, most identified and characterized GHs are from bacteria, in which their distribution across genomes is conserved within genera $[17,18]$. Many GH families with different activities have been detected in various fungal species. Although Ascomycetes and Basidiomycetes differ in the abundance of GH families, most glycoside hydrolases characterized from fungi have been reported to belong to the division Ascomycota [10,13]. Murphy and colleagues identified 453 fungal glycoside hydrolases from 131 fungal species which represented 49 different $\mathrm{GH}$ activities, and all were extracellular enzymes [13]. They indicated that the genus, Aspergillus, had the largest number of GH encoding genes. Comparative analysis of $\mathrm{GH}$ families across the entire fungal kingdom showed that Ascomycetes had more members of families GH2, GH72, and GH76 compared to Basidiomycetes. However, GH5, GH13, GH16, GH18 GH31, and GH61 are the most prevalent families among all fungi investigated to date [10]. In addition, it was reported that some GH families (e.g., GH7) mainly exist in fungi and oomycetes, but were not found in bacteria or archaea [19]. Based on the CAZy database, many characterized GHs show substrate specificity. For example, most identified proteins with domains from GH5, GH6, GH7, GH8, GH9, and GH12 families can act on cellulose, while GH18 and GH19 families act on chitin. However, some GH families show broad and mixed substrate specificity [18].

In recent years, the roles of CWDEs belonging to several GH families have been proved in invasion, pathogenicity or virulence of fungi and oomycetes on the plant host, but the exact mechanisms are still poorly understood [20-24]. Several studies indicated that pectinases [25], xylanases [26,27], xyloglucanases (XEGs) [28], cellulases [29-31], and chitinases [32], were related to pathogenicity of fungi. Pectate lyases were the first CWDE that were shown to be required for the full pathogenicity of Erwinia chrysanthemi causing the bacterial stem and root rot disease [33]. Since then, the role of many CWDEs in the virulence of various fungal pathogens has also been reported [28,30,31,34] (Figure 2). The role of pectate lyases as a virulence factor in the pathogenic fungi, Colletotrichum coccodes (a pathogen of potato and tomato), and Verticillium dahliae (a soil-borne fungus), has been well-described $[35,36]$. Moreover, disruption of both pectate lyase-genes in Fusarium solani f. sp. pisi, led to reduction of pathogenicity on pea [37]. Several studies have reported that some CWDEs, such as xyloglucanase (XEG1) [20-24] and endopolygalacturonases [38], can act as pathogen-associated molecular patterns (PAMPs), and induce PAMP-triggered immunity (PTI), in which their PAMP activity could be independent of their enzymatic activity. In V. dahliae, for example, a pectate lyase and a cutinase (VdPEL1 and VdCUT11, respectively) contributed to the fungal virulence and simultaneously activated plant immunity as PAMPs [36,39]. It has been reported that cellulases, xylanases, and cutinases play crucial roles in the virulence of Magnaporthe oryzae, the causal agent of rice blast disease $[30,40]$. CWDEs are important virulence factors in F. graminearum, the pathogen causing Fusarium head blight disease on wheat [41]. In addition, some CWDEs such as xylanases and hemicellulases are required for full pathogenicity of Valsa mali which causes a destructive disease on apple trees [42,43] (Table 1).

Table 1. Known glycoside hydrolase families in phytopathogenic fungi and oomycetes and their potential function.

\begin{tabular}{ccccc}
\hline Family & Enzymatic Activity & Fungal/Oomycete Species & Role & References \\
\hline GH5 & Endoglucanases; cellulasese & M. phaseolina & $\begin{array}{c}\text { Penetration of the cell } \\
\text { wall }\end{array}$ & $\begin{array}{c}\text { Penetration and } \\
\text { expansion of the } \\
\text { fungus in the host }\end{array}$ \\
\hline GH6 & Endoglucanases; cellulases & M. oryzae; A. alternata & Virulence factor \\
\hline GH7 & Endo- $\beta$-1,4-glucanases; cellulases & M. oryzae; $P$ sojae & Virulence factor & [30,31] \\
\hline GH10 & Endo-1,4- $\beta$-xylanases & M. oryzae &
\end{tabular}


Table 1. Cont.

\begin{tabular}{|c|c|c|c|c|}
\hline Family & Enzymatic Activity & Fungal/Oomycete Species & Role & References \\
\hline GH11 & Xylanases & $\begin{array}{c}\text { M. oryzae; B. cinerea; } \\
\text { Trichoderma sp.; } V \text {. dahliae }\end{array}$ & Virulence factor & {$[47-50]$} \\
\hline GH12 & Xyloglucanases & $\begin{array}{c}\text { F. oxysporum; } V . \text { dahliae } ; P . \\
\text { sojae }\end{array}$ & $\begin{array}{l}\text { Virulence factor; PAPM } \\
\text { activity and inducing } \\
\text { plant immune response }\end{array}$ & {$[20,24,51]$} \\
\hline GH13 & $\alpha$-amylases & $\begin{array}{l}\text { M. populorum; } \text { M. populicola; } \\
\text { M. oryzae; } R \text {. solani; } C \text {. } \\
\text { miyabeanus; M. graminicola }\end{array}$ & Stealth pathogenicity & [52-54] \\
\hline GH18 & Chitinases & $\begin{array}{l}\text { T. viride; C. rosea; } A \text {. nidulans; } \\
\text { M. oryzae; Mo. perniciosa; Mo. } \\
\text { roreri; P. xanthii }\end{array}$ & $\begin{array}{l}\text { Growth, nutrition, } \\
\text { mycoparasitism, } \\
\text { virulence factor; } \\
\text { suppression of } \\
\text { chitin-triggered } \\
\text { immunity }\end{array}$ & {$[32,55-59]$} \\
\hline GH45 & Endocellulases; Endoglucanases & R. solani & $\begin{array}{l}\text { PAMP activity and } \\
\text { inducing plant immune } \\
\text { response (PTI) }\end{array}$ & {$[60]$} \\
\hline GH74 & Xyloglucanases & C. vitis & Key virulence factor & [28] \\
\hline
\end{tabular}

A
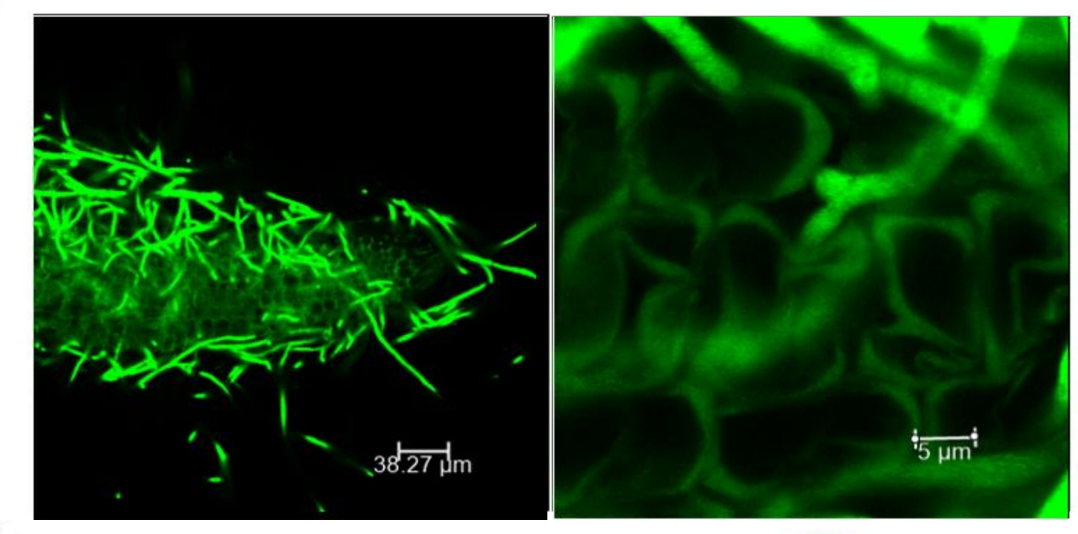

B

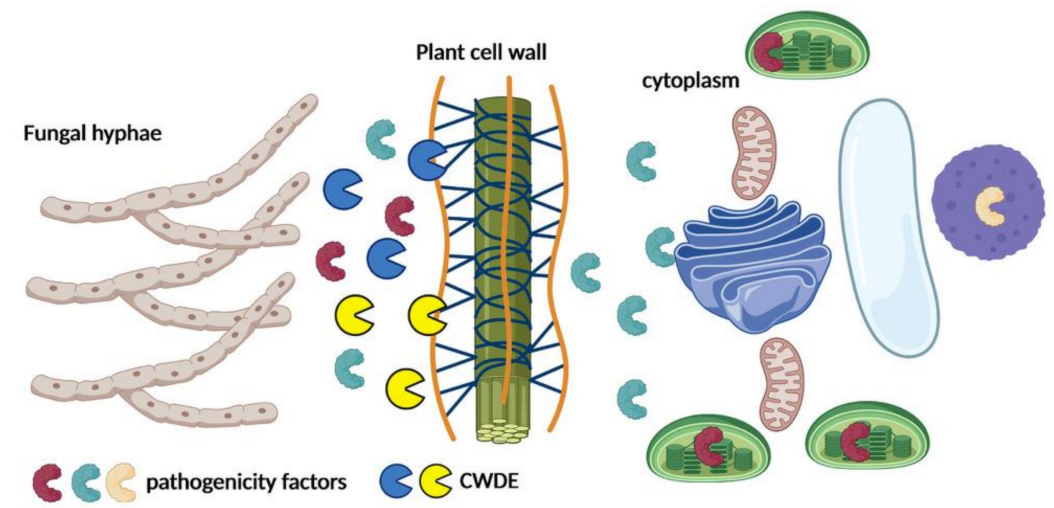

Figure 2. CWDEs are involved in host plant colonization. (A) Confocal scanning microscopy of Arabidopsis thaliana roots infected with the soil-borne pathogen, Verticillium longisporum, expressing the green fluorescent protein. To avoid recognition and successfully colonize its host, V. longisporum produces small secreted proteins as well as a repertoire of carbohydrate-active enzymes to degrade plant material [34]. Photo by Dr. Panagiotis Moschou (https:/ / pmoschoulab.wordpress.com/home/, accessed on 10 March 2021). Used with permission. (B) Schematic representation of the role of CWDEs in the establishment of a successful infection. Fungi secrete CDWEs in order to facilitate the penetration of pathogenicity factors to the plant cytoplasm. The figure was created by BioRender software. 


\section{Chitinases (Glycoside Hydrolases Family 18 and 19)}

GH families 18 and 19 in the CAZYme dataset include chitinolytic enzymes which are widely expressed in various organisms not only in fungi and insects, which contain chitin to their structures, but also to those who lack chitin in their cell walls such as plants, bacteria, and oomycetes [61,62]. GH18 family chitinases are predominant among fungi and plants. Chitinases from fungi are diverse and mainly reported in the GH family 18 which are associated with fungal development and autolysis [63,64]. Fungal chitinases were previously divided into three major clades known as A, B, and C; however, new phylogenetic analyses of GH18 proteins across many fungal genomes showed that chitinases previously assigned to the clade " $\mathrm{C}$ " were not distinct from the clade " $\mathrm{A}$ ", thus they were placed in one clade as AC. In addition, chitin-binding domains (CBDs) were not placed in certain specific clades and were identified widely across clades of chitinases [65].

Chitinases are responsible for the degradation of the $\beta-(1,4)$ linkages of chitin, a major polysaccharide component of the fungal cell wall, leading to the release of $\mathrm{N}$ acetylglucosamine oligomers [66,67]. Fungi deploy chitinases for various purposes. So far, the role of chitinases in the growth, nutrition, mycoparasitism, and virulence of fungi have been identified $[55,63,68]$. Filamentous fungi often contain expanded chitinase genes; for example, A. nidulans and A. fumigatus have 19 and 20 genes encoding GH18 enzymes, respectively. About 36 chitinase genes have been identified in Trichoderma virens, a mycoparasitic species [69]. The range of redundancy within the GH18 family can be problematic for studying the role of specific chitinase in fungi since it needs multiple deletion mutants for this purpose [70]. The genome of the fungus, M. oryzae, encodes 15 chitinases belonging to the GH18 family that are mostly essential for colonization of the host, suppression of host immunity, and fungal virulence [56].

Chitinases are also involved in fungal-fungal interactions. It has been shown that deletion of certain chitinase genes in Clonostachys rosea and $A$. nidulans results in a reduction of inhibitory activity against Botrytis cinerea and Rhizoctonia solani (Table 1) [57,58]. In plants, chitinases are classified into five classes and among them, classes III and V belong to the GH18 family, while Classes I, II, and IV belong to the GH19 family. Chitinases of the GH19 family have been reported mainly in plants and bacteria, and are thought to be produced as a defense mechanism against fungal invasion; thus, they are seldom found in fungi [62]. In this case, chitinases produced by plants can hydrolyze the chitin, the major component of the fungal cell wall. Released chitin oligomers act as PAMPs, which will be recognized by special chitin receptors including the chitin elicitor-binding protein (CEBiP) and the chitin elicitor receptor kinase (CERK1) [59] located in the plant cell surface and elicit a plant-defense response. Pathogenic fungi have developed different strategies to suppress chitin-triggered immunity in host plants, but the diversity of mechanisms that fungi use for suppression of plant response and pathogenicity is not clear [71]. For example, Cladosporium fulvum, the fungal pathogen of tomato, secretes two effector proteins known as extracellular protein 6 (ECP6) and avirulence protein 4 (AVR4), which bind to chitin molecules in the fungal cell wall to shield and protect the fungus against recognition by plants. AVR4 utilizes family 14 carbohydrate-binding module (CBM14) and ECP6 uses Lysin motif (LysM) domains to sequester chitin oligosaccharides released from hydrolysis of the fungal cell wall by plant chitinases to suppress elicitation of host immunity [72,73]. Most chitin-binding effectors in fungi contain LysM domains which are conserved and broadly distributed in the genomes indicating their essential roles in binding and protecting chitin in fungal cell walls against chitinases secreted by a plant during infection [73,74]. These effectors, with similar functions, have also been identified in other plant fungal pathogens, such as M. oryzae, Colletotrichum higginsianum, and $R$. solani $[59,75]$. It was reported that in M. oryzae, LysM-containing effector protein (Slp1) competes with CEBiP for chitin binding, thereby preventing the activation of immune response in rice [59].

Two fungal species in Basidiomycete class, threatening cacao production in America, Moniliophthora perniciosa and Mo. roreri (causing witches' broom disease and frosty pod rot on cacao, respectively), encode chitinase genes in the GH18 family known as MpChi 
and $\mathrm{MrChi}$, respectively. These genes were reported to be highly expressed during the interaction with cacao plants and encode catalytically inactive chitinases, which despite the lack of enzymatic activity, still bind to chitin oligomers and prevent elicitation of chitin-triggered immunity [71]. In other words, these chitinases act as virulence factors that chelate free chitin, thus preventing the activation of the plant immune system. Other plant-pathogenic fungi (e.g., Blumeria graminis, Colletotrichum spp., Fusarium spp., Puccinia spp., R. solani, and Va. mali) seem to encode putative inactive GH18 chitinases suggesting that similar strategies are likely used by other fungal phytopathogens (Table 1) [71].

Soil-borne fungal pathogens secrete proteins that can alter chitin in the fungal cell wall. It has been shown that $V$. dahliae and Fusarium sp., among the most destructive soil-borne fungal species, secrete polysaccharide deacetylase (PDA1) that are essential for fungal virulence. This chitin deacetylase can modify chitin oligomers to chitosan, preventing the perception of chitin by plant chitin receptors, therefore, suppressing chitin-triggered host immunity [76].

Recently, Martínez-Cruz et al. [32] characterized a new family of effectors in fungal pathogens acting as chitinases that are called effectors with chitinase activity (EWCAs). These fungal effectors degrade chitin oligomers but they do not have chitinolytic activity against the fungal cell wall. They investigated the function of these EWCA-like proteins in the cucurbit powdery mildew which causes by the fungus Podosphaera xanthii [77]. They indicated that these fungal chitinases are important for suppression of chitin-triggered immunity by breaking down chitin oligomers into smaller molecules that cannot be recognized by plant chitin receptors, avoiding the perception of chitin by plant immune system, and suppressing chitin-triggered host immunity. These EWCA proteins are conserved in the genomes of various fungal pathogens indicating their crucial roles in the successful infection and pathogenicity of fungi (Table 1) [32].

\section{Endoglucanases (Glycoside Hydrolase Families 5, 6, 7 and 45)}

Cellulose is one of the major polysaccharides in the cell wall of most plants and is the substrate of cellulase enzymes. Cellulases are produced by various microorganisms such as fungi, oomycetes, bacteria, and actinomycetes and hydrolyze the $\beta-1,4$-glycosidic bonds in cellulose polymer. Cellulases compose a group of enzymes including endoglucases, exoglucanases, and $\beta$-glucosidases [24,78]. Exoglucanases and endoglucanases act synergistically to produce cellobiose and are then cleaved by $\beta$-glucosidase to monosaccharides [38]. $\beta$-glucosidases are important in industrial biotechnology which hydrolyze glycosidic linkages and are distributed in glycoside families 1 and 3. Some cellulolytic fungi such as Trichoderma species are well recognized for their cellulose-degrading abilities and are typically used for biofuel production [79]. Several endoglucanases, exoglucanases, and $\beta$-glucosidases were isolated and purified from T. viride and T. reesei [80]. Although many fungi produce cellulases, the roles of these enzymes in pathogenicity and plantpathogen interactions are not fully understood. This may be due to the multiplicity of cellulase genes with similar functions throughout the fungal genomes [81]. For example, the genome of the fungus, M. oryzae, contains three and six genes encoding GH6 and GH7 cellulases, respectively.

Enzymes belonging to GH7 cleave the $\beta-1,4$-glucosidic bonds in the cellulose chain [82] Some GH7 members also act on xylan. GH7 enzymes are prevalent in fungi but have not been identified in bacteria or archaea [31]. It has been indicated that the GH6 and GH7 cellulases play important roles in the virulence of $M$. oryzae, involved in both penetration and expansion of the fungus in the host [30]. Construction of GH6 and GH7 multiple knockdown strains in M. oryzae, led to fewer lesions, less penetration, and infection of fewer cells. A high rate of papilla formation blocked the invasion of the knockdown mutants into host cells, indicating that GH6 and GH7 were involved in M. oryzae virulence. Interestingly, studies expressing $\mathrm{CH} 7$ cellulases of commercial value in heterologous systems have shown the importance of post-translational modifications (i.e., $\mathrm{N}$-terminal glutamine cyclization) for proper enzymatic function (Table 1) [83]. 
The endo-1,4- $\beta$-glucanase encoding gene AaK1, which belongs to the GH6 family, was reported in phytopathogenic fungus Alternaria alternata, and supposed to be an important virulence factor, facilitating disease development and penetration in fruits, while it was related to an increasing environmental $\mathrm{pH}$. Rising $\mathrm{pH}$ to 6.0 or higher, increased the expression of $A a K 1$ and production of endo-1,4- $\beta$-glucanase, which resulted in maximum virulence of $A$. alternata and its decay development on fruits [45]. Furthermore, a $\beta-1,4-$ endoglucanase encoding gene (egl1) has been reported in the soil-borne deuteromycete fungus, Macrophomina phaseolina which was unique and differed from any known endoglucanases in fungal saprophytes, belonging to the GH5 family (Table 1). Since the substrate of egl1 was similar to a plant-encoded endoglucanase which was active during plant cell wall expansion, it was speculated that egl1 was specific in phytopathogens and mimic the function of plant endoglucanases, facilitating surreptitious penetration of the cell wall [44].

In oomycetes, there is still little information available on the role of CWDEs. In Phytophthora sojae, a soil-borne oomycete causing soybean stem and root rot disease, the gene $P_{s} G H 7 a$ encoding a GH7 family cellulase was identified to be highly induced during infection, suggesting its important role in the invasion and virulence of this pathogen. In addition, this gene (PSGH7a) is highly conserved in both fungi and oomycetes and has a high percentage of identity for an amino acid sequence within the genus Phytophthora (Table 1) [31].

Cellulases can also act as elicitors in plant-pathogen interactions. The endoglucanase EG1, which belongs to the glycosyl hydrolase family 45, acts as an elicitor in the soil-borne plant pathogenic fungus, $R$. solani, which can induce cell death during infection. Moreover, it has been shown that full loss of its catalytic activity would not affect fungal infection suggesting that endoglucanase is an elicitor in fungi, but its cellulase activity is independent of its elicitor activity (Table 1) [60].

\section{Xylanases (Glycoside Hydrolase Families 10 and 11)}

Xylanases hydrolyze the $\beta-1,4$ bond in the xylan backbone of hemicellulose. This group of enzymes can be found in different glycoside hydrolase families, including GH5, GH7, GH8, GH10, GH11, and GH43 and have been reported in fungi, bacteria, and protozoa [84]. Most xylanases, which have been reported from fungi so far, belong to GH10 and GH11 families [85]. It has been reported that xylanases are required for the virulence of some phytopathogenic fungi. GH10 and GH11 endoxylanases were important pathogenicity factors in the fungus, $M$. oryzae during the infection process on rice. Since the reduction of virulence was higher in GH10 and GH11 mutants compared to GH6 and GH7 ones, it was speculated that GH10 and GH11 might have more important roles in cell wall penetration than the GH6 and GH7 cellulases (Table 1) [46]. Two genes (MGG_14243.6 and MGG_07868.6) from M. oryzae, encoding for GH10 enzymes were up-regulated upon infection of host plants, suggesting involvement in fungal virulence [30]. Silencing of multiple GH10 genes in the same fungal species showed a significant decrease in xylanase activity and reduced infection lesions on barley plants, indicating a crucial role of these enzymes in pathogenicity (Table 1) [30].

The xylanase $x y n 11 A$, belonging to the GH11 family, was shown to be essential for full virulence of the necrotrophic fungus B. cinerea. Catalytically impaired Xyn11A mutants did not eliminate the ability of necrosis induced by fungus, showing that Xyn11A contributed to virulence independently of enzymatic activity. Therefore, it was reported that Xyn11A promoted the necrosis of the plant tissue surrounding the infected plant areas, allowing the fungus to grow rapidly on necrotic tissues (Table 1) [47,48]. The same results had been previously observed in xylanases from other fungi. For example, it was shown that xylanases from Trichoderma species, contributed to virulence by eliciting necrosis in plant leaves, but its enzymatic activity was not required for its elicitor activity [49].

A protein from the GH11 family called $\mathrm{Vd} 424 \mathrm{Y}$ has been recently reported in the soilborne fungus, $V$. dahliae, and is an important effector protein targeting the plant nucleus and is necessary for full virulence of $V$. dahliae on its host (Table 1 ). It has been shown that 
both signal peptide and the nuclear localization signal are essential for Vd424Y-induced cell death. The transient expression of Vd424Y in Nicotiana benthamiana also induced plant cell death mediated by leucine-rich repeat (LRR) receptor-like kinases (PRR-RLKs), BAK1, and SOBIR1, indicating that Vd424Y is a potential PAMP that is able to activate PTI responses in plant [50].

\section{Xyloglucanases (Glycoside Hydrolase Families 12 and 74)}

Xyloglucanases (XEG) are one of the CWDEs that specifically break down xyloglucan, a major hemicellulosic component of the plant cell wall consisting of $\beta$-1,4-glucan linkages. They are found in bacteria, plants, and fungi and they mostly belong to GH12, GH74, and GH5 in the CAZY database $[28,86,87]$. To date, most of the xyloglucanases that have been studied in fungi belong to family GH12 and GH74 [20,28]. The structures of XEG enzymes in Clostridium thermocellum and Aspergillus niger have been well characterized [88,89]. It was reported that XEG belonging to the GH74 family acts as a virulence factor, which plays a significant role in the pathogenicity of Coniella vitis, the causal agent of grape white rot disease in China. The results of a recent study indicated the high level of hydrolytic activities of both xylanase and XEG in $C$. vitis during infection, while the deletion of XEG-

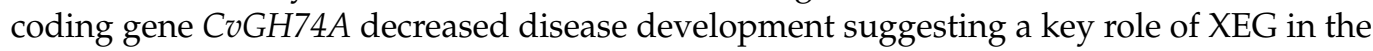
pathogenicity of the fungus (Table 1) [28].

Sato and colleagues reported that the hydrolytic activity of XEG was very high in the soil-borne fungus $V$. dahliae, but its role in pathogenicity was not clear [86]. However, Gui et al., [20] indicated that two of the six GH12 proteins produced by $V$. dahliae (VdEG1 and VdEG3) are virulence factors that act as PAPMs to trigger PTI regardless of their enzymatic activity (Table 1).

Recently, five proteins with GH12 domains have been found in the soil-borne vascular phytopathogenic fungus, F. oxysporum, among which, FoEG1 plays a crucial role in fungal pathogenicity as a virulence factor during interaction with its host [51]. FoEG1 is an apoplastic cell death-inducing protein, which is similar to VdEG1 from V. dahliae [20] and could be a PAMP to trigger plant cell death mediated by PRR-RLKs, BAK1, and SOBIR1 (Table 1). Thus, the results show that FoEG1 in F. oxysporum is an important virulence factor during infection and colonization by the fungus [51].

Genome mining of different oomycete, fungal, bacterial, and plant species showed that GH12 homologous-protein sequences of XEG1 were present and common in microbial taxa, but not in plants. In addition, among oomycete plant pathogens, a considerable amount of GH12 proteins were identified in Phytophthora species and in Hyaloperonospora arabidopsidis, but not in the necrotrophic oomycete, Pythium ultimum [24]. In P. sojae, the causal agent of stem and root rot of soybean, it was shown that XEG1 with xyloglucanase and $\beta$-glucanase activity could act as an important virulence factor during pathogen infection. In addition, XEG1 was recognized as a PAPMP and triggered an immune response in soybean and solanaceous species. Moreover, although XGE1 could be recognized as a PAPM by the host plant, several RXLR effectors secreted by P. sojae are able to suppress the plant-defense response triggered by XEG1, which underscores XGE1's role in pathogenicity (Table 1) [24].

\section{7. $\alpha$-Amylases (Glycoside Hydrolase Family 13)}

There is mounting evidence that $\alpha$-amylases, which belong to the GH13 family, maybe involved in stealth pathogenicity strategies by fungi to avoid host detection. The poplar pathogens, Mycosphaerella populorum and My. populicola, have a cluster composed of an $\alpha$-glucan synthase and $\alpha$-amylase that are co-expressed only when grown in the presence of wood chips [52]. Dhillon and colleagues went on to suggest that these fungi may be masking the chitin in their cell walls with $\alpha$-glucan to avoid host detection [52]. This cluster seems to be present in other fungal genomes, including some that are human pathogens. Similar strategies have been attributed to M. oryzae, R. solani, and Cochliobolus miyabeanus, since these fungi also mask their cell walls with $\alpha$-1,3-glucan, which cannot be degraded by the plant. The $\alpha-1,3$-glucan seems to offer protection against antifungal agents produced 
by the plant, limiting the production of PAMPs and thereby reducing the possibility of PTI [53]. Stealth pathogenicity conferred by $\alpha$-amylases has also been attributed to the wheat pathogen, Mycosphaerella graminicola (Table 1) [52,54].

\section{Conclusions}

Despite progress in understanding the various CWDEs with different glycoside hydrolase protein domains, there is still little knowledge on the role of these enzymes in the virulence of fungi. This is due to the extensive redundancy of genes encoding CWDEs in the fungal genome. Based on the genome sequence of plant pathogenic fungi, there are often more than 10 or 20 genes in a group of CWDEs in the genome. However, the results from many studies support the involvement and importance of several GH protein families in the virulence of phytopathogenic fungi. While major attention has been given to plant pathogenic fungi, the roles of CWDEs in oomycetes are still poorly understood, suggesting further investigation is needed to assess the roles of these enzymes in fungal-host interactions.

Funding: We thank Helge Axlesson Johnsons Stiftelse and Department of Forest Mycology and Plant Pathology for financially supported publication of this work.

Conflicts of Interest: The authors declare no conflict of interest. The funders had no role in the design of the study; in the collection, analyses, or interpretation of data; in the writing of the manuscript, or in the decision to publish the results.

\section{References}

1. Underwood, W. The plant cell wall: A dynamic barrier against pathogen invasion. Front. Plant Sci. 2012, 3, 85. [CrossRef]

2. Malinovsky, F.G.; Fangel, J.U.; Willats, W.G.T. The role of the cell wall in plant immunity. Front. Plant Sci. 2014, 5, 178. [CrossRef]

3. McNeil, M.; Darvill, A.G.; Fry, S.C.; Albersheim, P. Structure and function of the primary cell walls of plants. Annu. Rev. Biochem. 1984, 53, 625-663. [CrossRef]

4. Nühse, T.S. Cell wall integrity signaling and innate immunity in plants. Front. Plant Sci. 2012, 3, 280. [CrossRef]

5. Kameshwar, A.K.S.; Ramos, L.P.; Qin, W. CAZymes-based ranking of fungi (CBRF): An interactive web database for identifying fungi with extrinsic plant biomass degrading abilities. Bioresour. Bioprocess. 2019, 6, 51. [CrossRef]

6. Morales-Cruz, A.; Amrine, K.C.H.; Blanco-Ulate, B.; Lawrence, D.P.; Travadon, R.; Rolshausen, P.E.; Baumgartner, K.; Cantu, D. Distinctive expansion of gene families associated with plant cell wall degradation, secondary metabolism, and nutrient uptake in the genomes of grapevine trunk pathogens. BMC Genom. 2015, 16, 469. [CrossRef]

7. Pérez-Hernández, A.; González, M.; González, C.; van Kan, J.A.L.; Brito, N. BcSUN1, a B. cinerea SUN-family protein is involved in virulence. Front. Microbiol. 2017, 8, 35. [CrossRef]

8. Lagaert, S.; Beliën, T.; Volckaert, G. Plant cell walls: Protecting the barrier from degradation by microbial enzymes. Semin. Cell Dev. Biol. 2009, 20, 1064-1073. [CrossRef]

9. Lombard, V.; Golaconda Ramulu, H.; Drula, E.; Coutinho, P.M.; Henrissat, B. The carbohydrate-active en-zymes database (CAZy) in 2013. Nucleic Acids Res. 2014, 42, D490-D495. [CrossRef]

10. Zhao, Z.; Liu, H.; Wang, C.; Xu, J.R. Comparative analysis of fungal genomes reveals different plant cell wall degrading capacity in fungi. BMC Genom. 2013, 14, 274. [CrossRef]

11. Béguin, P.; Aubert, J.P. The biological degradation of cellulose. FEMS Microbiol. Rev. 1994, 13, 25-58. [CrossRef]

12. Scheller, H.V.; Ulvskov, P. Hemicelluloses. Annu. Rev. Plant Biol. 2010, 61, 263-289. [CrossRef]

13. Murphy, C.; Powlowski, J.; Wu, M.; Butler, G.; Tsang, A. Curation of characterized glycoside hydrolases of Fungal origin. Database 2011, 2011, bar020. [CrossRef]

14. Cantarel, B.L.; Coutinho, P.M.; Rancurel, C.; Bernard, T.; Lombard, V.; Henrissat, B. The carbohydrate-active EnZymes database (CAZy): An expert resource for glycogenomics. Nucleic Acids Res. 2009, 37, D233-D238. [CrossRef]

15. Henrissat, B.; Davies, G.J. Glycoside hydrolases and glycosyltransferases. Families, modules, and implications for genomics. Plant Physiol. 2000, 124, 1515-1519. [CrossRef]

16. Turbe-Doan, A.; Record, E.; Lombard, V.; Kumar, R.; Levasseur, A.; Henrissat, B.; Garron, M.L. Trichoderma reesei dehydrogenase, a pyrroloquinoline quinone-dependent member of auxiliary activity family 12 of the carbohydrate-active enzymes database: Functional and structural characterization. Appl. Environ. Microbiol. 2019, 85, e00964-19. [CrossRef]

17. Berlemont, R.; Martiny, A.C. Phylogenetic distribution of potential cellulases in bacteria. Appl. Environ. Microbiol. 2013, 79, 1545-1554. [CrossRef]

18. Berlemont, R.; Martiny, A.C. Glycoside hydrolases across environmental microbial communities. PLoS Comput. Biol. 2016, 12, e1005300. [CrossRef] 
19. Payne, C.M.; Knot, B.C.; Mayes, H.B.; Hansson, H.; Himmel, M.E.; Sandgren, M.; Ståhlberg, J.; Beckham, G.T. Fungal Cellulases. Chem. Rev. 2015, 115, 1308-1448. [CrossRef]

20. Gui, Y.J.; Chen, J.Y.; Zhang, D.D.; Li, N.Y.; Li, T.G.; Zhang, W.Q.; Wang, X.Y.; Short, D.P.G.; Li, L.; Guo, W.; et al. Verticillium dahliae manipulates plant immunity by glycoside hydro-lase 12 proteins in conjunction with carbohydrate-binding module 1. Environ. Microbiol. 2017, 19, 1914-1932. [CrossRef]

21. Snarr, B.D.; Baker, P.; Bamford, N.C.; Sato, Y.; Liu, H.; Lehoux, M.; Gravelat, F.N.; Ostapska, H.; Baistrocchi, S.R.; Cerone, R.P.; et al. Microbial glycoside hydrolases as antibiofilm agents with cross-kingdom activity. Proc. Natl. Acad. Sci. USA 2017, 114, 7124-7129. [CrossRef]

22. Le Mauff, F.; Bamford, N.C.; Alnabelseya, N.; Zhang, Y.; Baker, P.; Robinson, H.; Codée, J.D.C.; Howell, P.L.; Sheppard, D.C. Molecular mechanism of Aspergillus fumigatus biofilm disruption by fungal and bacterial glycoside hydrolases. J. Biol. Chem. 2019, 294, 10760-10772. [CrossRef]

23. Shen, D.; Wang, J.; Dong, Y.; Zhang, M.; Tang, Z.; Xia, Q.; Nyawira, K.T.; Jing, M.; Dou, D.; Xia, A. The glycoside hydrolase 18 family chitinases are associated with develop-ment and virulence in the mosquito pathogen Pythium guiyangense. Fungal Genet. Biol. 2020, 135, 103290. [CrossRef]

24. Ma, Z.; Song, T.; Zhu, L.; Ye, W.; Wang, Y.; Shao, Y.; Dong, S.; Zhang, Z.; Dou, D.; Zheng, X.; et al. A Phytophthora sojae glycoside hydrolase 12 protein is a major virulence factor during soybean infection and is recognized as a PAMP. Plant Cell 2015, 27, 2057-2072. [CrossRef] [PubMed]

25. Valette-Collet, O.; Cimerman, A.; Reignault, P.; Levis, C.; Boccara, M. Disruption of Botrytis cinerea pectin methylesterase gene Bcpme1 reduces virulence on several host plants. Mol. Plant Microbe Interact. 2003, 16, 360-367. [CrossRef]

26. Wanjiru, W.M.; Zhensheng, K.; Buchenauer, H. Importance of cell wall degrading enzymes produced by Fusarium graminearum during infection of wheat heads. Eur. J. Plant Pathol. 2002, 108, 803-810. [CrossRef]

27. Kang, Z.; Zingen-Sell, I.; Buchenauer, H. Infection of wheat spikes by Fusarium avenaceum and alterations of cell wall components in the infected tissue. Eur. J. Plant Pathol. 2005, 111, 19-28. [CrossRef]

28. Qin, J.; Li, B.; Zhou, S. A novel glycoside hydrolase 74 xyloglucanase CvGH74A is a virulence factor in Coniella vitis. J. Integr. Agric. 2020, 19, 2725-2735. [CrossRef]

29. Kang, Z.; Buchenauer, H. Ultrastructural and cytochemical studies on cellulose, xylan and pectin degrada-tion in wheat spikes infected by Fusarium culmorum. J. Phytopathol. 2000, 148, 263-275. [CrossRef]

30. Van Vu, B.; Itoh, K.; Nguyen, Q.B.; Tosa, Y.; Nakayashiki, H. Cellulases belonging to glycoside hydrolase fami-lies 6 and 7 contribute to the virulence of Magnaporthe oryzae. Mol. Plant Microbe Interact. 2012, 25, 1135-1141. [CrossRef]

31. Tan, X.; Hu, Y.; Jia, Y.; Hou, X.; Xu, Q.; Han, C.; Wang, Q. A conserved glycoside hydrolase family 7 cellobio-hydrolase PsGH7a of Phytophthora sojae is required for full virulence on soybean. Front. Microbiol. 2020, 11, 1285. [CrossRef]

32. Martínez-Cruz, J.; Romero, D.; Hierrezuelo, J.; Thon, M.; de Vicente, A.; Pérez-García, A. Effectors with chi-tinase activity (EWCAs), a family of conserved, secreted fungal chitinases that suppress chitin-triggered immunity. Plant Cell 2021, 33, 1319-1340. [CrossRef]

33. Hugouvieux-Cotte-Pattat, N.; Condemine, G.; Nasser, W.; Reverchon, S. Regulation of pectinolysis in Erwinia chrysanthemi. Annu. Rev. Microbiol. 1996, 50, 213-257. [CrossRef] [PubMed]

34. Leonard, M.; Kühn, A.; Harting, R.; Maurus, I.; Nagel, A.; Starke, J.; Kusch, H.; Valerius, O.; Feussner, K.; Feussner, I.; et al Verticillium longisporum elicits media-dependent secretome re-sponses with capacity to distinguish between plant-related environments. Front. Microbiol. 2020, 11, 21. [CrossRef]

35. Ben-Daniel, B.H.; Bar-Zvi, D.; Tsror Lahkim, L. Pectate lyase affects pathogenicity in natural isolates of Colletotrichum coccodes and in pelA gene-disrupted and gene-overexpressing mutant lines. Mol. Plant Pathol. 2012, 13, 187-197. [CrossRef]

36. Yang, Y.; Zhang, Y.; Li, B.; Yang, X.; Dong, Y.; Qiu, D. A Verticillium dahliae pectate lyase induces plant im-mune responses and contributes to virulence. Front. Plant Sci. 2018, 9, 271. [CrossRef]

37. Rogers, L.M.; Kim, Y.K.; Guo, W.; González-Candelas, L.; Li, D.; Kolattukudy, P.E. Requirement for either a host- or pectin-induced pectate lyase for infection of Pisum sativum by Nectria hematococca. Proc. Natl. Acad. Sci. USA 2000, 97, 9813-9818. [CrossRef]

38. Zhang, L.; Kars, I.; Essenstam, B.; Liebrand, T.W.; Wagemakers, L.; Elberse, J.; Tagkalaki, P.; Tjoitang, D.; van den Ackerveken, G.; van Kan, J.A. Fungal endopolygalacturonases are recognized as microbe-associated molecular patterns by the Arabidopsis receptor-like protein responsiveness to Botrytis polygalacturonases. Plant Physiol. 2014, 164, 352-364. [CrossRef]

39. Muchero, W.; Sondreli, K.L.; Chen, J.-G.; Urbanowicz, B.R.; Zhang, J.; Singan, V.; Yang, Y.; Brueggeman, R.S.; Franco-Coronado, J.; Abraham, N.; et al. Association mapping, transcriptomics, and transient expression identify candidate genes mediating plant-pathogen interactions in a tree. Proc. Natl. Acad. Sci. USA 2018, 115, 11573-11578. [CrossRef]

40. Quoc, N.B.; Bao Chau, N.N. The Role of cell wall degrading enzymes in pathogenesis of Magnaporthe oryzae. Curr. Protein Pept. Sci. 2017, 18, 1019-1034. [CrossRef]

41. Kikot, G.E.; Hours, R.A.; Alconada, T.M. Contribution of cell wall degrading enzymes to pathogenesis of Fusarium graminearum: A review. J. Basic Microbiol. 2009, 49, 231-241. [CrossRef]

42. Xu, M.; Gao, X.; Chen, J.; Yin, Z.; Feng, H.; Huang, L. The feruloyl esterase genes are required for full patho-genicity of the apple tree canker pathogen Valsa mali. Mol. Plant Pathol. 2018, 19, 1353-1363. [CrossRef]

43. Yu, C.; Li, T.; Shi, X.; Saleem, M.; Li, B.; Liang, W.; Wang, C. Deletion of endo- $\beta-1,4$-xylanase VmXyl1 impacts the virulence of Valsa mali in Apple Tree. Front Plant Sci. 2018, 9, 663. [CrossRef] 
44. Wang, H.; Jones, R.W. A unique endoglucanase-encoding gene cloned from the phytopathogenic fungus Macrophomina phaseolina. Appl. Environ. Microbiol. 1995, 61, 2004-2006. [CrossRef]

45. Eshel, D.; Miyara, I.; Ailing, T.; Dinoor, A.; Prusky, D. pH regulates endoglucanase expression and virulence of Alternaria alternata in persimmon fruit. Mol. Plant Microbe Interact. 2002, 15, 774-779. [CrossRef]

46. Nguyen, Q.B.; Itoh, K.; van Vu, B.; Tosa, Y.; Nakayashiki, H. Simultaneous silencing of endo- $\beta-1,4$ xylanase genes reveals their roles in the virulence of Magnaporthe oryzae. Mol. Microbiol. 2011, 81, 1008-1019. [CrossRef] [PubMed]

47. Brito, N.; Espino, J.J.; González, C. The endo- $\beta-1,4-x y l a n a s e$ Xyn11A is required for virulence in Botrytis cinerea. Mol. Plant Microbe Interact. 2006, 19, 25-32. [CrossRef] [PubMed]

48. Noda, J.; Brito, N.; González, N. The Botrytis cinerea xylanase Xyn11A contributes to virulence with its ne-crotizing activity, not with its catalytic activity. BMC Plant Biol. 2010, 10, 38. [CrossRef] [PubMed]

49. Enkerli, J.; Felix, G.; Boller, T. The enzymatic activity of fungal xylanase is not necessary for its elicitor activity. Plant Physiol. 1999, 121, 391-397. [CrossRef]

50. Liu, L.; Wang, Z.; Li, J.; Wang, Y.; Yuan, J.; Zhan, J.; Wang, P.; Lin, Y.; Li, F.; Ge, X. Verticillium dahliae secreted protein $\mathrm{Vd} 424 \mathrm{Y}$ is required for full virulence, targets the nucleus of plant cells, and induces cell death. Mol. Plant Pathol. 2021, 22, 1109-1120. [CrossRef] [PubMed]

51. Zhang, L.; Yan, J.; Fu, Z.; Shi, W.; Ninkuu, V.; Li, G.; Yang, X.; Zeng, H. FoEG1, a secreted glycoside hydrolase family 12 protein from Fusarium oxysporum, triggers cell death and modulates plant immunity. Mol. Plant Pathol. 2021, 22, 522-538. [CrossRef]

52. Dhillon, B.; Feau, N.; Aerts, A.L.; Beauseigle, S.; Bernier, L.; Copeland, A.; Foster, A.; Gill, N.; Henrissat, B.; Herath, P.; et al. Horizontal gene transfer and gene dosage drives adaptation to wood colonization in a tree pathogen. Proc. Natl. Acad. Sci. USA 2015, 112, 3451-3456. [CrossRef]

53. Fujikawa, T.; Sakaguchi, A.; Nishizawa, Y.; Kouzai, Y.; Minami, E.; Yano, S.; Koga, H.; Meshi, T.; Nishimura, M. Surface $\alpha-1,3$-glucan facilitates fungal stealth infection by interfering with innate immunity in plants. PLoS Pathog. 2012, 8, e1002882. [CrossRef] [PubMed]

54. Goodwin, S.B.; Ben M’Barek, S.; Dhillon, B.; Wittenberg, A.H.J.; Crane, C.F.; Hane, J.K.; Foster, A.J.; Van Der Lee, T.A.J.; Grimwood, J.; Aerts, A.; et al. Finished genome of the fungal wheat pathogen Mycosphaerella graminicola reveals dispensome structure, chromosome plasticity, and stealth pathogenesis. PLoS Genet. 2011, 7, e1002070. [CrossRef] [PubMed]

55. Tzelepis, G.; Karlsson, M. Killer toxin-like chitinases in filamentous fungi: Structure, regulation and potential roles in fungal biology. Fungal Biol. Rev. 2019, 33, 123-132. [CrossRef]

56. Han, Y.; Song, L.; Peng, C.; Liu, X.; Liu, L.; Zhang, Y.; Wang, W.; Zhou, J.; Wang, S.; Ebbole, D.; et al. A Magnaporthe chitinase interacts with a rice jacalin-related lectin to pro-mote host colonization. Plant Physiol. 2019, 179, 1416-1430. [CrossRef] [PubMed]

57. Tzelepis, G.; Melin, P.; Stenlid, J.; Jensen Funck, D.; Karlsson, M. Functional analysis of the C-II subgroup kill-er toxin-like chitinases in the filamentous ascomycete Aspergillus nidulans. Fungal Genet. Biol. 2014, 64, 58-66. [CrossRef]

58. Tzelepis, G.; Dubey, M.; Jensen Funck, D.; Karlsson, M. Identifying glycoside hydrolase family 18 genes in the mycoparasitic fungal species Clonostachys rosea. Microbiology 2015, 161, 1407-1419. [CrossRef]

59. Mentlak, T.A.; Kombrink, A.; Shinya, T.; Ryder, L.S.; Otomo, I.; Saitoh, H.; Terauchi, R.; Nishizawa, Y.; Shibuya, N.; Thomma, B.P.; et al. Effector-mediated suppression of chitin-triggered immunity by Magnaporthe oryzae is necessary for rice blast disease. Plant Cell 2012, 24, 322-335. [CrossRef]

60. Ma, Y.; Han, C.; Chen, J.; Li, H.; He, K.; Liu, A.; Li, D. Fungal cellulase is an elicitor but its enzymatic activity is not required for its elicitor activity. Mol. Plant Pathol. 2015, 16, 14-26. [CrossRef]

61. Funkhouser, J.D.; Aronson, N.N. Chitinase family GH18: Evolutionary insights from the genomic history of a diverse protein family. BMC Evol. Biol. 2007, 7, 96. [CrossRef]

62. Tzelepis, G.; Karlsson, M. The fungal chitinases. In Encyclopedia of Mycology; Zaragoza, O., Ed.; Elsevier: Oxford, UK, 2021; Volume 1, pp. 23-31.

63. Merzendorfer, H.; Zimoch, L. Chitin metabolism in insects: Structure, function and regulation of chitin synthases and chitinases. J. Exp. Biol. 2003, 206, 4393-4412. [CrossRef]

64. Hartl, L.; Zach, S.; Seidl-Seiboth, V. Fungal chitinases: Diversity, mechanistic properties and biotechnological potential. Appl. Microbiol. Biotechnol. 2012, 93, 533-543. [CrossRef] [PubMed]

65. Goughenour, K.D.; Whalin, J.; Slot, J.C.; Rappleye, C.A. Diversification of fungal chitinases and their functional differentiation in Histoplasma capsulatum. Mol. Biol. Evol. 2021, 38, 1339-1355. [CrossRef] [PubMed]

66. Bussink, A.P.; Speijer, D.; Aerts, J.M.F.G.; Boot, R.G. Evolution of mammalian chitinase(-like) members of family 18 glycosyl hydrolases. Genetics 2007, 177, 959-970. [CrossRef] [PubMed]

67. Xia, G.; Jin, C.; Zhou, J.; Yang, S.; Zhang, S.; Jin, C. A novel chitinase having a unique mode of action from Aspergillus fumigatus YJ-407. Eur. J. Biochem. 2001, 268, 4079-4085. [CrossRef]

68. Carsolio, C.; Gutiérrez, A.; Jiménez, B.; van Montagu, M.; Herrera-Estrella, A. Characterization of ech-42, a Trichoderma harzianum endochitinase gene expressed during mycoparasitism. Proc. Natl. Acad. Sci. USA 1994, 91, 10903-10907. [CrossRef]

69. Kubicek, C.P.; Herrera-Estrella, A.; Seidl-Seiboth, V.; Martinez, D.A.; Druzhinina, I.S.; Thon, M.; Zeilinger, S.; Casas-Flores, S.; Horwitz, B.A.; Mukherjee, P.K.; et al. Comparative genome sequence analysis under-scores mycoparasitism as the ancestral life style of Trichoderma. Genome Biol. 2011, 12, R40. [CrossRef] 
70. Langner, T.; Göhre, V. Fungal chitinases: Function, regulation, and potential roles in plant/pathogen interactions. Curr. Genet. 2016, 62, 243-254. [CrossRef]

71. Fiorin, G.L.; Sanchéz-Vallet, A.; Thomazella, D.P.T.; do Prado, P.F.V.; do Nascimento, L.C.; Figueira, A.V.O.; Thomma, B.P.H.J.; Pereira, G.A.G.; Teixeira, P.J.P.L. Suppression of plant immunity by fungal chitinase-like effectors. Curr. Biol. 2018, 28, 3023-3030. [CrossRef]

72. Van den Burg, H.A.; Harrison, S.J.; Joosten, M.H.A.; Vervoort, J.; de Wit, P.J.G.M. Cladosporium fulvum Avr4 protects fungal cell walls against hydrolysis by plant chitinases accumulating during infection. Mol. Plant Microbe Interact. 2006, 19, 1420-1430. [CrossRef]

73. De Jonge, R.; van Esse, H.P.; Kombrink, A.; Shinya, T.; Desaki, Y.; Bours, R.; van der Krol, S.; Shibuya, N.; Joosten, M.H.A.J.; Thomma, B.P.H.J. Conserved fungal LysM effector Ecp6 prevents chitin-triggered immunity in plants. Science 2010, 329, 953-955. [CrossRef] [PubMed]

74. Hurlburt, N.K.; Chen, L.H.; Stergiopoulos, I.; Fisher, A.J. Structure of the Cladosporium fulvum Avr4 effector in complex with (GlcNAc)6 reveals the ligand-binding mechanism and uncouples its intrinsic function from recognition by the Cf-4 resistance protein. PLoS Pathog. 2018, 14, e1007263. [CrossRef] [PubMed]

75. Dölfors, F.; Holmquist, L.; Dixelius, C.; Tzelepis, G. A LysM effector protein from the basidiomycete Rhi-zoctonia solani contributes to virulence through suppression of chitin-triggered immunity. Mol. Genet. Genom. 2019, 294, 1211-1218. [CrossRef] [PubMed]

76. Gao, F.; Zhang, B.S.; Zhao, J.H.; Huang, J.F.; Jia, P.S.; Wang, S.; Zhang, J.; Zhou, J.M.; Guo, H.S. Deacetylation of chitin oligomers increases virulence in soil-borne fungal pathogens. Nat. Plants 2019, 5, 1167-1176. [CrossRef]

77. Vela-Corcía, D.; Bautista, R.; de Vicente, A.; Spanu, P.D.; Pérez-García, A. De novo analysis of the epiphytic transcriptome of the cucurbit powdery mildew fungus Podosphaera xanthii and identification of candidate secreted effector proteins. PLoS ONE 2016, 11, e0163379. [CrossRef] [PubMed]

78. Jayasekara, S.; Ratnayake, R. Microbial cellulases: An overview and applications. In Cellulose; IntechOpen: London, UK, 2019. [CrossRef]

79. Tiwari, P.; Misra, B.N.; Sangwan, N.S. $\beta$-glucosidases from the fungus Trichoderma: An efficient cellulase ma-chinery in biotechnological applications. Biomed. Res. Int. 2013, 2013, 203735. [CrossRef]

80. Beldman, G.; Leeuwen, M.F.; Rombouts, F.M.; Voragen, F.G.J. The cellulase of Trichoderma viride. Purification, characterization and comparison of all detectable endoglucanases, exoglucanases and beta-glucosidases. Eur. J. Biochem. 1985, 146, 301-308. [CrossRef]

81. Espino, J.J.; Brito, N.; Noda, J.; González, C. Botrytis cinerea endo-ß-1,4-glucanase Cel5A is expressed during infection but is not required for pathogenesis. Physiol. Mol. Plant Pathol. 2005, 66, 213-221. [CrossRef]

82. Gilkes, N.R.; Henrissat, B.; Kilburn, D.G.; Miller, R.C.; Warren, R.A. Domains in microbial beta-1, 4-glycanases: Sequence conservation, function, and enzyme families. Microbiol. Rev. 1991, 55, 303-315. [CrossRef]

83. Dana, C.M.; Dotson-Fagerstrom, A.; Roche, C.M.; Kal, S.M.; Chokhawala, H.A.; Blanch, H.W.; Clark, D.S. The importance of pyroglutamate in cellulase Cel7A. Biotechnol. Bioeng. 2014, 111, 842-847. [CrossRef] [PubMed]

84. Sizova, M.V.; Izquierdo, J.A.; Panikov, N.S.; Lynd, L.R. Cellulose- and xylan-degrading thermophilic anaero-bic bacteria from biocompost. Appl. Environ. Microbiol. 2011, 77, 2282-2291. [CrossRef]

85. Meng, D.D.; Ying, Y.; Chen, X.H.; Lu, M.; Ning, K.; Wang, L.S.; Li, F.L. Distinct roles for carbohydrate-binding modules of glycoside hydrolase 10 (GH10) and GH11 xylanases from Caldicellulosiruptor sp. strain F32 in thermostability and catalytic efficiency. Appl. Environ. Microbiol. 2015, 81, 2006-2014. [CrossRef] [PubMed]

86. Sato, S.; Ohta, K.; Kojima, K.; Kozeki, T.; Ohmachi, T.; Yoshida, T. Isolation and characterization of two types of xyloglucanases from a phytopathogenic fungus, Verticillium dahliae. J. Appl. Glycosci. 2016, 63, 13-18. [CrossRef] [PubMed]

87. Gusakov, A.V. Additional sequence and structural characterization of an endo-processive GH74 xyloglu-canase from Myceliophthora thermophila and the revision of the EC 3.2.1.155 entry. Biochim. Biophys. Acta Gen. Subj. 2020, 1864, 129511. [CrossRef] [PubMed]

88. Martinez-Fleites, C.; Guerreiro, C.I.; Baumann, M.J.; Taylor, E.J.; Prates, J.A.; Ferreira, L.M.; Fontes, C.M.; Brumer, H.; Davies, G.J. Crystal structures of Clostridium thermocellum xyloglucanase, XGH74A, reveal the structural basis for xyloglucan recognition and degradation. J. Biol. Chem. 2006, 281, 24922-24933. [CrossRef] [PubMed]

89. Master, E.R.; Zheng, Y.; Storms, R.; Tsang, A.; Powlowski, J. A xyloglucan-specific family 12 glycosyl hydro-lase from Aspergillus niger: Recombinant expression, purification and characterization. Biochem. J. 2008, 411, 161-170. [CrossRef] 